\title{
Impact of sulfur on density of Tetranychus pacificus (Acari: Tetranychidae) and Galendromus occidentalis (Acari: Phytoseiidae) in a central California vineyard
}

\author{
Michael J. Costello \\ Horticulture and Crop Science Department, California Polytechnic State University, San Luis Obispo, \\ CA 93407, USA
}

\begin{abstract}
Sulfur is the oldest and most widely used fungicide in the vineyards of California, where it is used for control of powdery mildew (Uncinula necator [Schw.] Burr). For decades, sulfur use has been associated with outbreaks of Tetranychus pacificus McGregor (Acari: Tetranychidae) on cultivated grapes in the San Joaquin Valley. I undertook large-scale field studies to test this association, to evaluate the impact of sulfur on Galendromus occidentalis (Nesbit) (Acari: Phytoseiidae), a major predator of T. pacificus, and to determine if timing of sulfur applications with respect to grape bloom has an impact on T. pacificus density. The studies took place in a 32 ha vineyard in Fresno County, and all fungicide applications were made with commercial-scale equipment. In 1998 a 'high sulfur' treatment, a combination of wettable sulfur and sulfur dust, was compared to 'low sulfur,' in which demethylation inhibitor (DMI) fungicides partially substituted for sulfur. In 1999 treatments were 'sulfur,' 'DMI,' 'sulfur pre-bloom' (here sulfur was applied prior to grape bloom, in late May, and then DMIs were applied until mid-season) and 'sulfur post-bloom' (the reverse of 'sulfur pre-bloom'). In each year, the T. pacificus population increase came after the end of fungicide applications, and results clearly show a relationship between sulfur use and T. pacificus density. In 1998, mean $T$. pacificus density was 2.7 times higher and mean G. occidentalis density 2.5 times higher in 'high sulfur' compared to 'low sulfur.' In 1999, the highest T. pacificus counts were in the 'sulfur' and 'sulfur pre-bloom' treatments, 4.8 times higher than 'sulfur post-bloom' and 2 times higher than 'DMIs.' Density of G. occidentalis was 2.3 times as high in 'sulfur' or 'sulfur pre-bloom' than 'DMIs.' The predator/prey ratio was not significantly different among treatments in 1998, but in 1999 it was highest in the 'sulfur pre-bloom' treatment. In 1999, density of Homeopronematus anconai (Baker) (Acari: Tydeidae) was 2.7 times
\end{abstract}


higher in 'sulfur pre-bloom' compared to 'sulfur,' and higher by 2.7 times in 'DMI' compared to 'sulfur post-bloom,' suggesting a negative effect of sulfur on this tydeid. These results do not support the hypotheses that the cause of the increase in T. pacificus density is due to negative effects of sulfur on phytoseiids or tydeids. Rather, it appears that a plant-based explanation is likely, first, because of the differences in pre-bloom versus post-bloom sulfuring, and second, because of the long lag time between the end of the sulfur applications and the corresponding increase in spider mite density.

Keywords Spider mites · Vineyard $\cdot$ Sulfur $\cdot$ Grape $\cdot$ Phytoseiids $\cdot$ Fungicides

\section{Introduction}

Spider mites (Tetranychidae) are one of the most significant arthropod pest groups of grapes in California. In any given year, some $20-25 \%$ of commercial acreage is treated with miticides for either Pacific spider mite (Tetranychus pacificus McGregor) or Willamette spider mite (Eotetranychus willametti [McGregor]). In 2005 an estimated 89,285 ha-applications were made with miticides (California Department of Pesticide Regulation 2006).

It is well known that spider mite population density can be influenced by various environmental conditions, including plant water status (English-Loeb 1989), plant nitrogen status (Wood and Reilly 2000), dust, or poor soil conditions such as compaction, extremes of $\mathrm{pH}$ and shallow soil (Flaherty et al. 1992). Another factor that has been associated with outbreaks of T. pacificus is sulfur (Smith 1950; English-Loeb et al. 1986; Hanna et al. 1997; James et al. 2002). Sulfur is used for control of grape powdery mildew or oidium (Uncinula necator [Schw.] Burr), the most important fungal disease of grapes in California, and one of the most significant grape diseases worldwide. Sulfur has been used on grapes in the state for about as long as grapes have been commercially cultivated (ca. 1840), and is still the fungicide of choice for $U$. necator because of its ease of application and low cost, and because the fungus has never developed resistance. It is the most widespread and commonly used fungicide on grapes in California, with over 20 million $\mathrm{kg}$ used in 2005 (California Department of Pesticide Regulation 2006). Sulfur dust is the most common formulation, and it is used primarily from late spring till mid-summer. Sulfur in wettable powder form (wettable sulfur) is also used, but typically in early spring when the canopy is light. California Department of Pesticide Regulation statistics do not distinguish between the two formulations, so the amount of each used cannot be estimated. In the warm climate of the San Joaquin Valley, sulfur applications cease in mid-season (late June or early July), partly because increased sugar accumulation increases berry resistance to new fungal infections, and partly because fungal development is arrested with temperatures over $35^{\circ} \mathrm{C}$, which are typical during July and August.

Sulfur use on grapevines has been associated with $T$. pacificus outbreaks in the central San Joaquin Valley for many decades. It was first reported as an observed pattern in which the beginning of major increases in T. pacificus density corresponded to the end of the season for U. necator (Smith 1950), and, correspondingly, the cessation of sulfur application. More recently, the pattern has been noted in Washington State (James et al. 2002), and two California studies showed that substituting synthetic fungicides (e.g., sterol 
demethylation inhibitors [DMIs]) for sulfur can dramatically lower T. pacificus density (English-Loeb et al. 1986; Hanna et al. 1997). In addition, one of these (Hanna et al. 1997) found that sulfur decreased density of the western predatory mite (Galendromus [=Metaseiulus] occidentalis [Nesbit]) and suggested that this was the cause for increased density of T. pacificus. However, earlier laboratory studies had found a fair amount of resistance to sulfur in $G$. occidentalis collected from commercial vineyards versus commercial orchards or native plants (Hoy and Standow 1982). Still, the hypothesis that sulfur is detrimental to phytoseiids has been generally accepted by practitioners.

Other studies have found that sulfur decreases populations of Tydeidae (English-Loeb et al. 1999). One hypothesis is that, because phytoseiids may feed on tydeids as an alternative prey, its low density may correspond to a dearth of predatory mites. The most common tydeid in central California vineyards is Homeopronematus anconai (Baker), an omnivore which feeds on pollen, fungal spores, eriophyiids and spider mite eggs.

Another possible explanation for the relation between sulfur and T. pacificus density is that sulfur suppresses a fungal pathogen of the mite; however, this seems unlikely given the high humidity requirements of arthropod-invading fungi and the dry summer condition in the San Joaquin Valley.

I undertook field studies to follow up on previous work involving sulfur, T. pacificus and G. occidentalis, on a commercial-size scale. In year one the questions to be answered were straightforward: does substitution of synthetic fungicides for sulfur decrease $T$. pacificus density, and does reliance on sulfur as a fungicide decrease density of G. occidentalis? In year two of the studies I added one more question: is there a difference in $T$. pacificus density when sulfur is applied exclusively before the bloom period (i.e., from budbreak to early bloom, typically early-April to mid/late-May) versus post-bloom (i.e., from berry set to veraison [increase in berry sugar], typically late-May/early June to early July)?

\section{Materials and methods}

The field study site was a 32-ha block of grapes cultivated for raisin production, cv. 'Thompson Seedless' (aka 'Sultana'), approximately $12 \mathrm{~km}$ south of Kerman, in Fresno County. In-row vine spacing was $2.1 \mathrm{~m}$, with $3.6 \mathrm{~m}$ between rows. Soil type at the site was a Hanford fine sandy loam.

In 1998 I compared spider mite and phytoseiid mite density on vines treated almost exclusively with either wettable sulfur or sulfur dust ('high sulfur' treatment) to vines treated with a combination of sulfur in wettable powder form and DMIs ('low sulfur' treatment). The experiment was designed as a randomized complete block, with four replications. Plot size was 2.6 ha $\left(402 \times 64.8 \mathrm{~m}^{2}\right.$, or 190 vines $\times 18$ rows $)$.

Applications of sulfur dust were done with a commercial vineyard duster, and applications of copper hydroxide, wettable sulfur or DMIs were done with an air-blast sprayer using cone-shaped nozzles. Both machines were pulled by a commercial tractor.

In each of the study years, the entire field site received an application of copper hydroxide $\left(\right.$ Champ2 ${ }^{\circledR}$ ) at $2.31 /$ ha and wettable sulfur (Microthiol ${ }^{\circledR} 80 D F$ ) at $3.4 \mathrm{~kg} / \mathrm{ha}$ in $4.7 \mathrm{hl}$ of water shortly after budbreak (first week of April) to aid in control of U. necator. Also, the bloomtime application for the entire study site included $6.7 \mathrm{~kg} / \mathrm{ha}$ of sodium fluoroaluminate (Kryocide ${ }^{\circledR}$ ) for control of Platynota stultana Walsingham (Lepidoptera: Tortricidae) and 2.3 1/ha of $6 \%$ zinc solution. 
In 1998, in the 'high sulfur' treatment, sulfur dust was applied at a rate of $11.2 \mathrm{~kg} / \mathrm{ha}$ in $4.7 \mathrm{hl}$ of water on 17 and 24 April; 9 and 18 May; and 18 and 24 June. For the bloomtime spray on 8 June a combination of wettable sulfur at $3.4 \mathrm{~kg} / \mathrm{ha}$ and myclobutanil (Rally ${ }^{\circledR}$ 40WSP) at $0.37 \mathrm{l} / \mathrm{ha}$ in $9.3 \mathrm{hl}$ of water was applied.

In the 'low sulfur' treatment, wettable sulfur (Microthiol ${ }^{\circledR} 80 \mathrm{DF}$ ) was applied at $3.4 \mathrm{~kg} /$ ha in $4.7 \mathrm{hl}$ of water on 17 April; 8 and 18 June; and 3 July. The same formulation was applied at $4.5 \mathrm{~kg} / \mathrm{ha}$ in $4.7 \mathrm{hl}$ of water on 30 April, and at $5.6 \mathrm{~kg} / \mathrm{ha}$ in $7.0 \mathrm{hl}$ of water on 9 and 18 May. For the bloomtime spray of 8 June, myclobutanil (Rally ${ }^{\circledR} 40 \mathrm{~W}$ ) was applied at $0.37 \mathrm{l} / \mathrm{ha}$ in $9.3 \mathrm{hl}$ of water, and on 18 June and 3 July fenarimol (Rubigan ${ }^{\circledR}$ EC) was applied at $0.44 \mathrm{l} / \mathrm{ha}$ in $9.3 \mathrm{hl}$ of water.

In 1999 I repeated the study, but with the addition of timing relative to the grape bloom period as a variable, for a total of four treatments. Treatments were: 'sulfur,' 'DMIs,' 'sulfur pre-bloom' and 'sulfur post-bloom.' The experiment was designed as a randomized complete block, with four replications. Plot size was 2.6 ha $\left(402 \times 64.8 \mathrm{~m}^{2}\right.$, or 190 vines $\times 18$ rows).

In the 'sulfur' treatment, sulfur dust was applied at a rate of $11.2 \mathrm{~kg} / \mathrm{ha}$ on 15,22 and 29 April; 8 and 15 May; and 2, 10, 21 and 30 June. In addition, wettable sulfur (Microthiol ${ }^{\circledR}$ 80DF) was applied at $3.4 \mathrm{~kg} / \mathrm{ha}$ in $9.3 \mathrm{hl}$ of water for the bloomtime spray on 24 May.

In the 'DMI' treatment, triflumizole (Procure ${ }^{\circledR} 50 \mathrm{WS}$ ) was applied at $0.35 \mathrm{~kg} / \mathrm{ha}$ in $4.7 \mathrm{hl}$ of water on 13 and 28 April; and in $7.0 \mathrm{hl}$ of water on 12 May. Fenarimol (Rubigan ${ }^{\circledR} \mathrm{EC}$ ) was applied at $0.44 \mathrm{l} / \mathrm{ha}$ in $9.3 \mathrm{hl}$ of water for the bloomtime spray on 24 May; and on 8 and 22 June.

In the 'sulfur pre-bloom' treatment, sulfur was applied at the same rates and on the same dates as in 'sulfur' until after the bloom spray, and then DMIs were applied at the same rates and on the same dates as in the 'DMI' treatment.

In the 'sulfur post-bloom treatment,' DMIs were applied at the same rates and on the same dates as in the 'DMI' treatment until after the bloom spray, then sulfur was applied at the same rates and on the same dates as in the 'sulfur' treatment.

A summary of sulfur applications for each of the study years is in Table 1.

Sampling began in May of each year. Using a binomial method, we conducted weekly visual inspections, recording the percentage of leaves with mite colonies. When this value reached about 5\%, we collected leaf samples (30 leaves per plot in 1998 and 20 leaves per plot in 1999) and took them to the laboratory for processing. There we processed them through a mite brushing machine (Leedom Industries, Mi-Wok Village, CA) onto a glass plate coated with a thin solution of glycerol, corn syrup and detergent. We processed ten leaves at a time, and $10 \%$ of the plate was counted in a cross-grid, for a final estimate of mites/leaf. We recorded numbers of T. pacificus and G. occidentalis (adults and juveniles combined), and, in 1999, numbers of the tydeid H. anconai.

Cumulative mite-days (CMD) were calculated for T. pacificus, using the formula:

$$
\Sigma(\text { mean mites/leaf week } \mathrm{X}+\text { mean mites/leaf week } \mathrm{X}+1) / 2 * 7 \text {. }
$$

Predator-prey ratio was calculated as:

$$
\frac{\text { Mites/leaf G.occidentalis }}{\text { Mites/leaf T.pacificus }}
$$

and was averaged for each treatment on each sampling date. 
Table 1 Summary of sulfur applications, 1998 and 1999
Sulfur applications

$\begin{array}{ll}\begin{array}{l}1998 \text { Treatment } \\ \text { 'High sulfur' }\end{array} & \text { Six sulfur dust } \\ & \text { Two wettable sulfur } \\ & \text { Total }=73 \mathrm{~kg} / \mathrm{ha} \\ \text { 'Low sulfur' } & \text { Eight wettable sulfur } \\ & \text { Total }=26 \mathrm{~kg} / \mathrm{ha} \\ \text { 1999 Treatment } & \\ \text { 'Sulfur' } & \text { Ninesulfur dust } \\ & \text { Two wettable sulfur } \\ & \text { Total }=108 \mathrm{~kg} / \mathrm{ha} \\ \text { 'Sulfur pre-bloom' } & \text { Five sulfur dust } \\ & \text { Four wettable sulfur } \\ & \text { Total }=62.8 \mathrm{~kg} / \mathrm{ha} \\ \text { 'Sulfur post-bloom' } & \text { Four sulfur dust } \\ & \text { Five wettable sulfur } \\ & \text { Total }=48.2 \mathrm{~kg} / \mathrm{ha} \\ \text { 'DMI' } & \text { One wettable sulfur } \\ & \text { Total }=3.4 \mathrm{~kg} / \mathrm{ha} \\ & \end{array}$

Spider mite, phytoseiid and tydeid density, and predator/prey ratios, were analyzed by repeated measures analysis of variance. In 1999, treatment means were separated by orthogonal contrasts, contrasting 'sulfur' + 'sulfur pre-bloom' versus 'DMI' + 'sulfur postbloom,' 'sulfur' versus 'sulfur pre-bloom' and 'DMI' versus 'sulfur post-bloom' (PROC GLM, SAS Institute 2001). Cumulative mite days were analyzed by analysis of variance (PROC GLM, SAS Institute 2001), using Tukey's HSD for mean separation (SAS Institute 2001).

\section{Results}

1998

In 1998, mite-brush sampling began on 25 June, but T. pacificus numbers remained relatively low until $16 \mathrm{July}$, when density began to increase dramatically, i.e., by eightfold in the 'high sulfur' treatment between 9 July and 16 July (Fig. 1). From this point on until the end of the sampling period, density was consistently higher in the 'high sulfur' treatment compared to 'low sulfur.' Density peaked at $65.8 \pm 10.8$ mites/leaf on 19 August in the 'high sulfur' treatment, and at $25.1 \pm 4.6$ mites/leaf on 6 August in the 'low sulfur' treatment (Fig. 1). Over all sampling dates, mean T. pacificus density was 2.7 times higher in the 'high sulfur' treatment than in the 'low sulfur' treatment (Table 2). Similarly, mean cumulative mite days were 2.5 times higher under 'high sulfur' compared to 'low sulfur' (Table 3).

Density of G. occidentalis was higher in 1998 on most dates under 'high sulfur' versus 'low sulfur,' peaking at $4.16 \pm 2.16$ /leaf on 6 August in the 'high sulfur' treatment, and at 


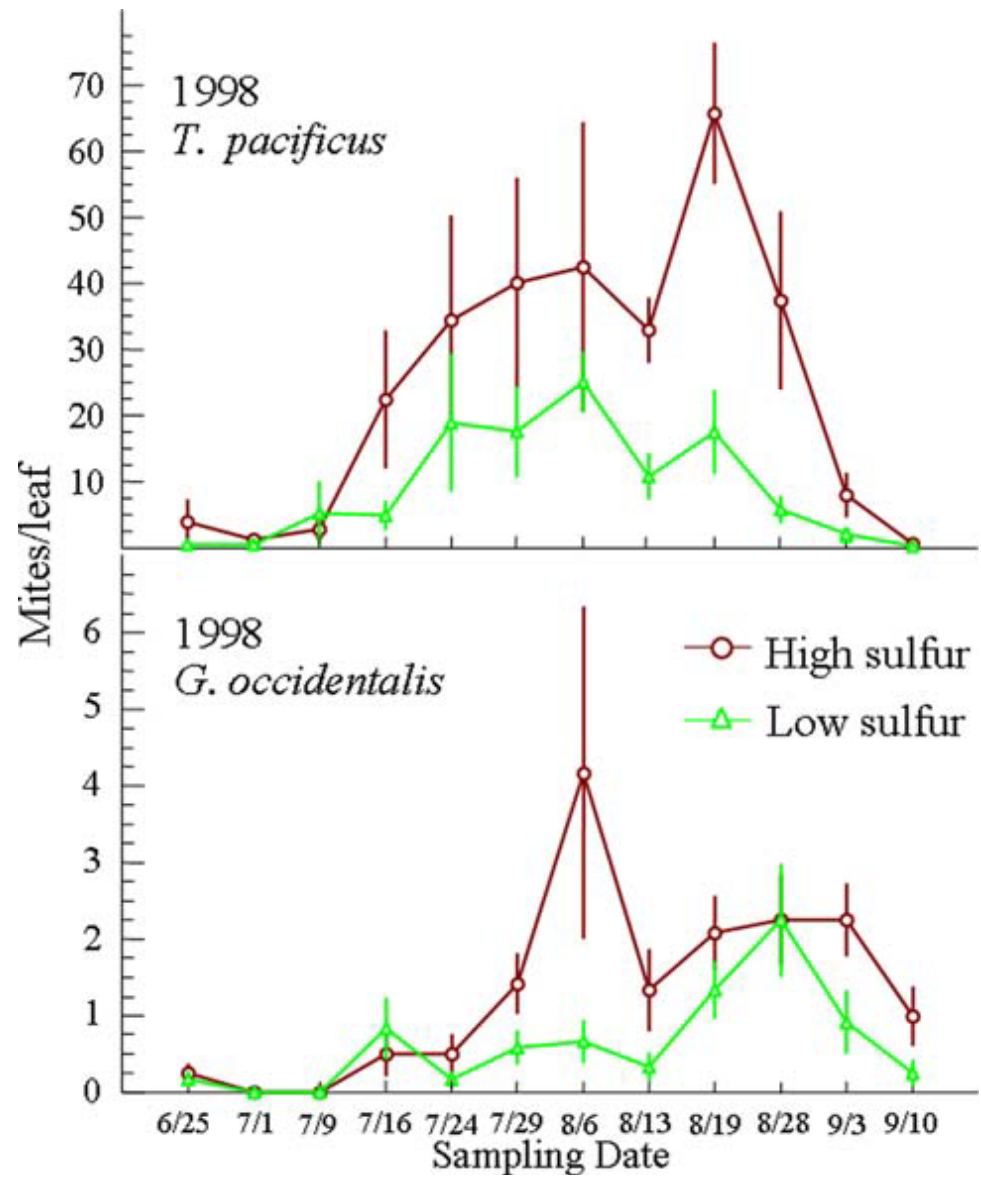

Fig. 1 Density of T. pacificus and G. occidentalis (mean mites per leaf \pm standard error) under 'high-' and 'low sulfur' treatments, 1998 season. Overall, in 'high sulfur,' density of T. pacificus was more than two and a half times greater $(P<0.0001)$ and $G$. occidentalis density two times greater $(P=0.0008)$, than 'low sulfur'

Table 2 Mean seasonal T. pacificus and G. occidentalis densities (mites/leaf) and repeated measures analysis of variance in 'high sulfur' and 'low sulfur' treatments, 1998

Mean T. pacificus \pm standard error Mean G. occidentalis \pm standard error

High sulfur

$24.3 \pm 3.5$

$1.31 \pm 0.22$

Low sulfur

$9.1 \pm 1.5$

$0.63 \pm 0.10$

Repeated measures ANOVA $F=10.14$, df $=1,194, P=0.0049 \quad F=10.57$, df $=1,19, P=0.0042$

$2.25 \pm 0.74 /$ leaf on 28 August in 'low sulfur' (Fig. 1). Over all sampling dates, mean $G$. occidentalis density was twofold higher in the 'high sulfur' treatment than the 'low sulfur' treatment $(F=11.6, \mathrm{df}=1,280, P=0.0008)$. However, the predator/prey ratio was not much different over the course of the season (Fig. 2), averaging ( \pm standard error) $0.255 \pm 0.032$ in the 'high sulfur' treatment and $0.246 \pm 0.044$ in the 'low sulfur' treatment, and was not significantly different overall (repeated measures ANOVA $\mathrm{F}=1.26, \mathrm{df}=1,19$, $P=0.2762)$. 
Table 3 Cumulative mite-days for $T$. pacificus and analysis of variance in high sulfur versus low sulfur treatments, 1998 and 1999 seasons

Means followed by different letters are significantly different at $P<0.05$
1998

Mean mite-days \pm standard error

\begin{tabular}{ll}
\hline High sulfur & $2587 \pm 305$ \\
Low sulfur & $1041 \pm 68$ \\
ANOVA & $F=83.6, \mathrm{df}=1,112, P<0.0001$ \\
1999 & Mite-days \\
Sulfur & $3578 \pm 601 \mathrm{a}$ \\
Sulfur pre-bloom & $2680 \pm 390 \mathrm{a}$ \\
Sulfur post-bloom & $1006 \pm 285 \mathrm{~b}$ \\
DMI & $321 \pm 64 \mathrm{c}$ \\
ANOVA & $F=93.05, \mathrm{df}=3,16, P<0.0001$ \\
\hline
\end{tabular}

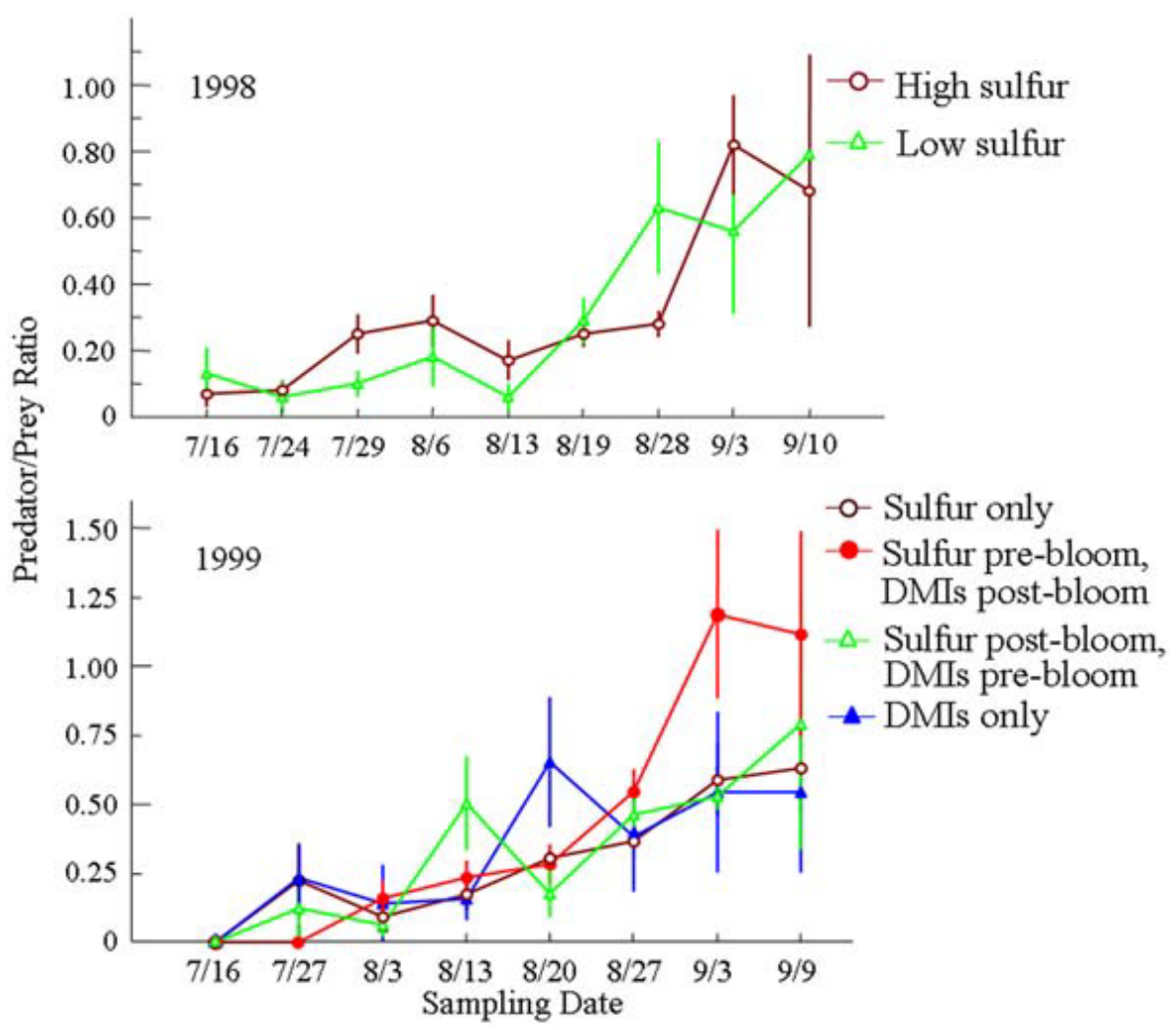

Fig. 2 Ratio of G. occidentalis density to T. pacificus density (predator-prey ratio) over the course of the 1998 and 1999 seasons. There was no significant overall difference in the predator-prey ratio in 1998, but in 1999 'sulfur pre-bloom' was significantly higher than 'sulfur' $(P=0.0118)$

In 1999 sampling for mite brushing began on 16 July, followed by a steep rate of increase in T. pacificus density (by six-fold from 16 July to 27 July in the 'sulfur' treatment). From 27 July to the end of the study, there was a clear separation in density between 'sulfur' and 'sulfur pre-bloom' on one hand, and 'DMI' and 'sulfur post-bloom' on the other, with the former consistently higher (Fig. 3). Tetranychus pacificus density in the 'sulfur' treatment peaked at $72.5 \pm 15.6 /$ leaf on 24 July, and at $63.4 \pm 8.4$ on 16 July in the 'sulfur pre-bloom' 


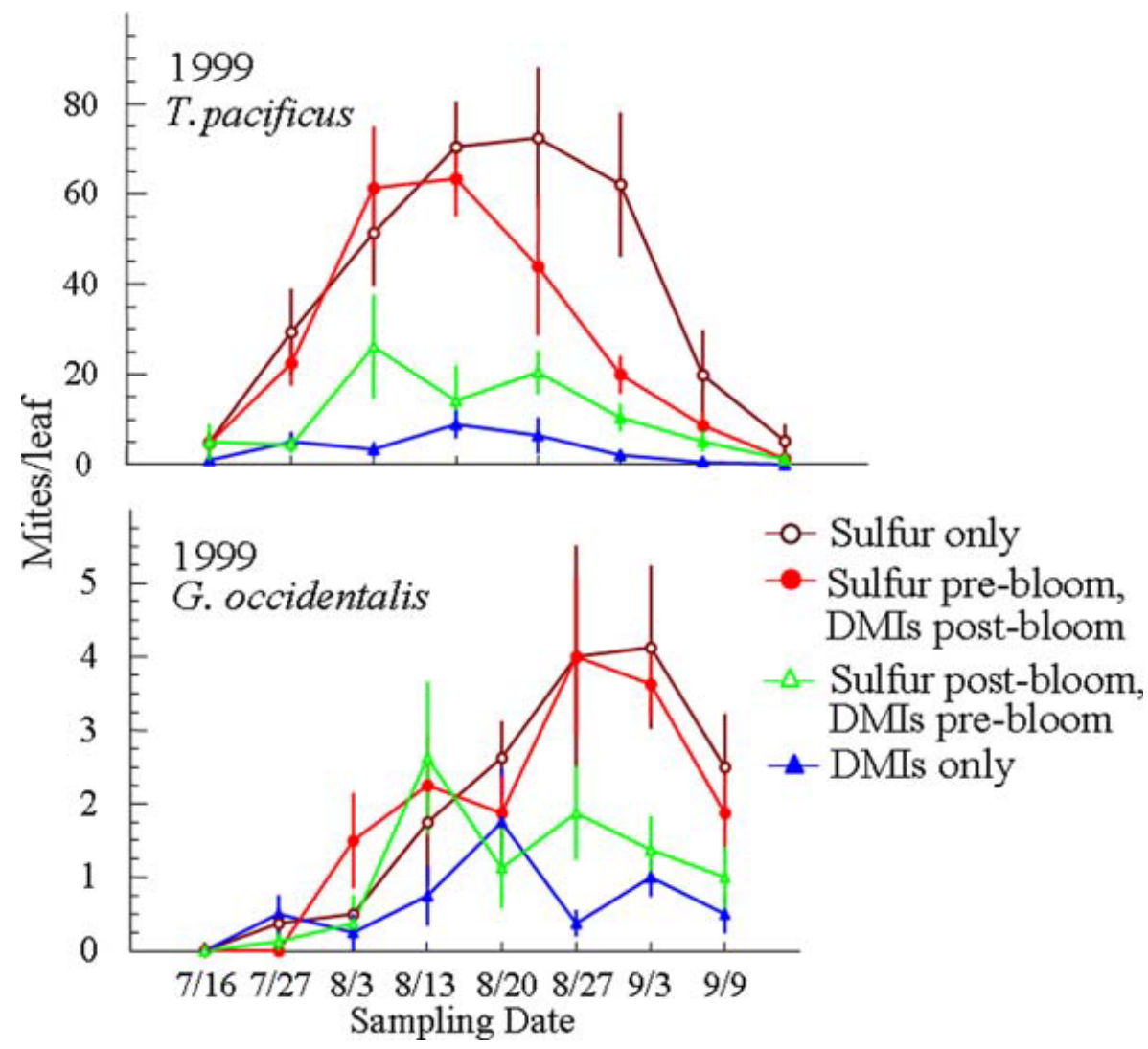

Fig. 3 Density of T. pacificus and G. occidentalis (mean mites per leaf \pm standard error) under 'sulfur,' 'sulfur pre-bloom,' 'sulfur post-bloom,' and 'DMI' treatments, 1999 season. Overall, there was a more than fourfold difference between T. pacificus density in the 'sulfur' or 'sulfur pre-bloom' treatments compared to the 'DMI' and 'sulfur post-bloom' treatments $(P<0.0001)$. Density of $G$. occidentalis was more than twice as high 'sulfur,' and 'sulfur pre-bloom' versus 'DMI' and 'sulfur post-bloom' treatments 'DMI' $(P<0.0001)$

Table 4 Mean seasonal T. pacificus and G. occidentalis densities (mites/leaf) in 'sulfur,' 'sulfur prebloom,' 'sulfur post-bloom,' and 'DMI' treatments, plus repeated measures analysis of variance and orthogonal contrasts, 1999

$\begin{array}{lc}\begin{array}{l}\text { Mean } T . \text { pacificus (mites/ } \\ \text { leaf) } \pm \text { standard error }\end{array} & \begin{array}{l}\text { Mean G. occidentalis (mites/ } \\ \text { leaf) } \pm \text { standard error }\end{array} \\ 39.5 \pm 4.9 & 1.98 \pm 0.32 \\ 28.2 \pm 4.0 & 1.89 \pm 0.26 \\ 10.8 \pm 2.1 & 1.06 \pm 0.21 \\ 3.4 \pm 0.8 & 0.64 \pm 0.13 \\ F=35.84, \mathrm{df}=3,67, & F=3.21, \mathrm{df}=3,67, \\ P<0.0001 & P=0.0286 \\ F=96.05, \mathrm{df}=1,67, & F=4.15, \mathrm{df}=1,67, \\ P<0.0001 & P=0.0456 \\ F=27.91, \mathrm{df}=1,67, & P=0.17, \mathrm{df}=1,67, \\ P<0.0001 & F=5.20, \mathrm{df}=1,67, \\ F=0.67, \mathrm{df}=1,67, & P=0.0258\end{array}$

Sulfur

Sulfur pre-bloom

Sulfur post-bloom

DMI

Repeated measures ANOVA

Contrast: 'sulfur' and 'sulfur pre-bloom' versus 'DMI' and 'sulfur post-bloom'

Contrast: 'sulfur' versus 'sulfur pre-bloom'

Contrast: 'sulfur post- bloom' versus 'DMI'

$$
P=0.417
$$


treatment. On the other end, peak T. pacificus density was $26.1 \pm 11.7$ on 9 July in the 'sulfur post-bloom' treatment and just $8.8 \pm 3.1$ in the 'DMI' treatment. There was a significant difference in season-wide spider mite density among treatments, with mean density highest in the 'sulfur' and 'sulfur pre-bloom' treatments, together 4.8 times higher than combined 'DMI' and 'sulfur-post bloom' (Table 4). Density under 'sulfur' was slightly but significantly higher (by 39.8\%) than 'sulfur pre-bloom' but 'sulfur post-bloom' did not differ significantly from 'DMI' (Table 4).

Mean cumulative mite days showed similar results to mean overall spider mite density: the overall ANOVA was significant $(F=93.05, \mathrm{df}=3,16, P<0.0001)$, with 'sulfur' and 'sulfur pre-bloom' totals twice as high as 'sulfur post-bloom' and 8.7 times as high than 'DMI' $(P<0.05$, Tukey's HSD) (Table 3). There was no significant difference between 'sulfur' and 'sulfur pre-bloom,' but 'sulfur post-bloom' was 2.1 times as high as 'DMI' $(P<0.05$, Tukey's HSD) (Table 3).

Galendromus occidentalis density in 1999 also showed a clear separation between 'sulfur' and 'sulfur pre-bloom' on one hand, and 'DMI' and 'sulfur post-bloom' on the other, a pattern which was similar to that of T. pacificus (Fig. 3). Galendromus occidentalis density peaked at 4.1/leaf on 3 Sept. in the 'sulfur' treatment, and at 4.0/leaf on 27 Aug. in the 'sulfur pre-bloom' treatment, and 2.6/leaf on 13 Aug. in 'sulfur post-bloom' and 1.8/ leaf on 13 Aug. in 'DMI' (Fig. 3). Over the season, G. occidentalis density in the 'sulfur' plus 'sulfur pre-bloom' treatments was 2.3 times higher than 'DMI' and 'sulfur postbloom' (Table 4). Density was 65\% higher in 'sulfur post-bloom' than 'DMI' but did not differ significantly between 'sulfur' and 'sulfur pre-bloom' (Table 4). And, in 1999 the predator-prey ratio was similar among treatments for most of the season, increasing somewhat in the 'sulfur pre-bloom' treatment at the end of the season (Fig. 2). Overall, the ratio differed significantly (repeated measures ANOVA $F=3.10, \mathrm{df}=3,25, P=0.0447$ ), but the contrast of the mean ratio ( \pm standard error) in 'sulfur' $(0.295 \pm 0.04)$ and 'sulfur pre-bloom' $(0.429 \pm 0.07)$ versus 'DMI' $(0.323 \pm 0.07)$ and 'sulfur-post bloom'

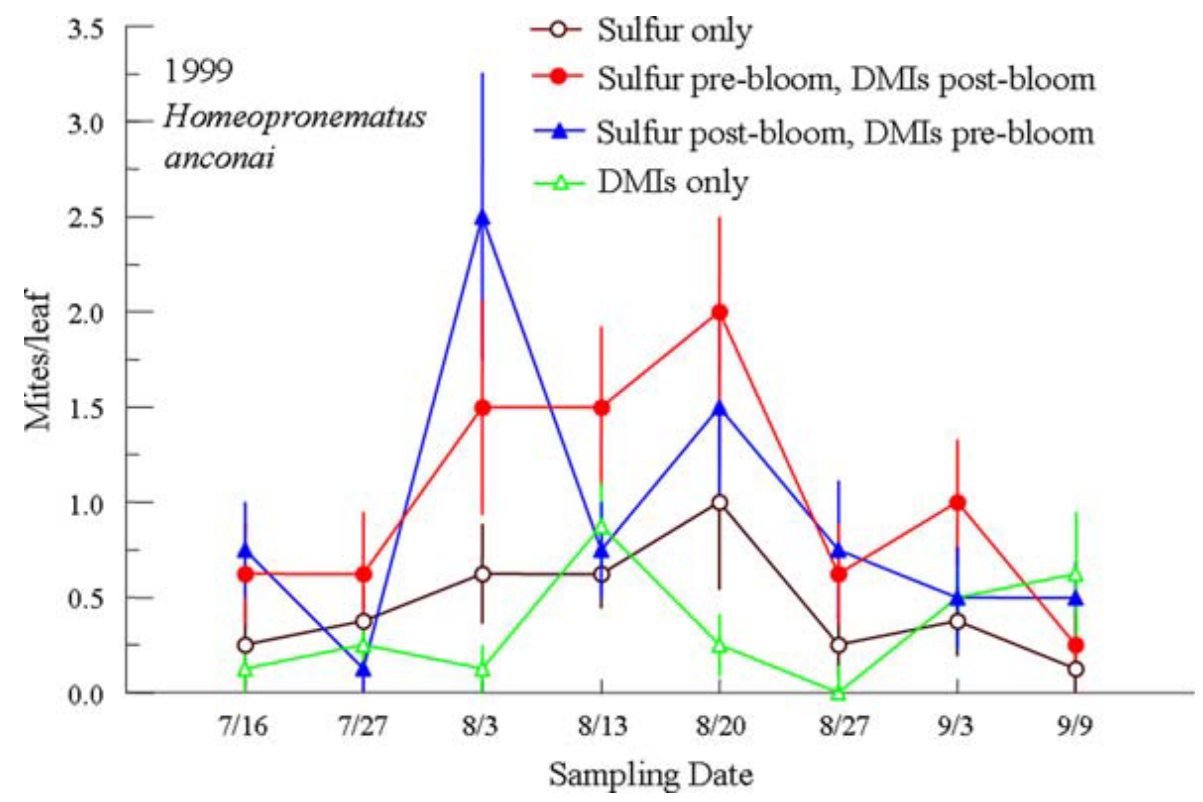

Fig. 4 Density of $H$. anconai (mean mites per leaf \pm standard error) over the course of the 1999 season. Density in the 'sulfur pre-bloom' treatment was 2.2 times higher than 'sulfur' and 'DMI' was 2.7 times higher than 'sulfur post-bloom' $(P=0.0016)$ 
$(0.303 \pm 0.054)$ was not significant $(F=1.91, \mathrm{df}=3,25, P=0.178)$, nor was the contrast of 'DMI' versus 'sulfur post-bloom' $(F=0.01, \mathrm{df}=3,25, P=0.933)$. However, the overall 'sulfur pre-bloom' ratio was 1.5 times higher than 'sulfur' (contrast $F=7.39$, df $=3,25$, $P=0.0118$ ).

Density of $H$. anconai in 1999 was significantly different overall among the treatments (repeated measures ANOVA $F=8.43$, df $=3,25, P=0.0005$ ) (Fig. 4). Here the split was not between 'sulfur' and 'sulfur pre-bloom' on one end and 'DMI' 'sulfur post-bloom' on the other, as this contrast was not significantly different $(F=0.78$, $\mathrm{df}=1,25, P=0.3863)$. Rather, 'sulfur pre-bloom' was 2.2 times higher than 'sulfur' $(F=11.93$, df $=1,25$, $P=0.002)$ and 'DMI' was 2.7 times higher than 'sulfur post-bloom' $(F=12.60, \mathrm{df}=1,25$, $P=0.0016)$.

\section{Discussion}

These studies clearly show a relationship between increased T. pacificus density and sulfur use, confirming previous observations (Smith 1950) and experiments (English Loeb et al. 1986; Hanna et al. 1997; James et al. 2002). This, however, contrasts with the fact that sulfur has been used as a mite control tool for hundreds of years. More recently, Prishmann et al. (2005), found that sulfur suppressed density of Tetranychus mcdanieli McGregor in an Oregon 'Reisling' vineyard, and recent laboratory assays have confirmed the miticidal properties of sulfur, with mortality dependent on environmental conditions such as temperature and humidity (Auger et al. 2003). However, as earlier studies showed, and the present studies confirm, the answer to this paradox is that the increase in spider mite density does not begin until after sulfur applications cease (Figs. 1, 3). Therefore, sulfur may very well directly suppress T. pacificus density, but there also appears to be an indirect effect that begins after sulfur applications cease and persists long afterward, enabling spider mite population buildup. Curiously, in the present studies, as well as in English Loeb et al. (1986) and Hanna et al. (1997), mite density in the low-sulfur or DMI fungicide treatments also did not increase until the end of fungicide applications. Although it is possible that DMI fungicides have a negative effect on T. pacificus, this is not likely, given that another study found no toxic effects of these materials on a related species, Tetranychus urticae (Alston and Thompson 2004).

These studies provide no evidence for a long term negative effect of sulfur on $G$. occidentalis, although, as with T. pacificus, there may have been a direct but temporary suppression of the phytoseiid population, given its very low density until about 4 weeks after the cessation of fungicide applications. On the other hand, this low predator density may have been largely due to a lack of prey items. In any case, these results provide no support for the hypothesis that the increase in spider mite density in the high sulfur treatments is explained by lack of predatory mites. In the current study, phytoseiid density was highest where spider mite density was highest: in the high sulfur or sulfur pre-bloom treatments (Figs. 1, 3). This, of course, makes perfect sense in terms of predator-prey dynamics. And, when density of G. occidentalis was adjusted for density of T. pacificus (i.e., the predator/prey ratio) there was little difference among treatments, the only significant effect being a higher ratio in the 'sulfur pre-bloom' treatment in 1999, largely due to a high increase in the index over the last two sampling dates (Fig. 2). These findings are in contrast to those of Hanna et al (1997), who, while also working in a San Joaquin Valley vineyard, found overall post-treatment density of G. occidentalis twofold lower under a 
sulfur-only fungicide regime compared to DMIs. However, the current results are almost exactly as those of English-Loeb et al. (1986) who found peak post-treatment G. occidentalis density about sixfold higher on sulfur-treated versus triadimefon (a triazole fungicide) treated vines.

It is quite logical that commercial vineyard populations of G. occidentalis in California have evolved some resistance to sulfur, for several reasons: first, because sulfur is used extensively in the state (virtually every commercial vineyard receives several to many sulfur applications per year). Second, two factors increase the selection pressure for resistance: the mites are exposed to treated plant material at all life stages, and, because they have no wings, they cannot easily emigrate from treated vineyards. Each of these factors more quickly eliminates susceptible members of the population, leaving a higher proportion with resistant genes. Hoy and Standow (1982), found a high degree of resistance to sulfur in G. occidentalis from San Joaquin Valley commercial vineyards compared to natural areas. Indeed, there are recent findings of sulfur being detrimental to phytoseiids (Prishmann et al. 2005; Teodoro et al. 2005), but these seem to be from populations which had not been exposed to sulfur for some time. For example, Prishmann et al. (2005) worked in a vineyard which had been abandoned for over 15 years, and Teodoro et al. (2005) used specimens from a pesticide-free coffee plantation.

The possibility that DMI fungicides had a direct negative effect on $G$. occidentalis might be considered, but is highly unlikely given that a recent study (Alston and Thompson 2004) found no effect of two DMIs, triflumazole and myclobutanil, on this species.

There is also a possibility that sulfur or the DMI fungides may differentially affect other macropredators of spider mites. However, this cannot explain the results of the current studies, given that the only other spider mite predator present in this vineyard, Scolothrips sexmaculatus (Perande), was not found until late in the season in each of the study years, after the population of $T$. pacificus had begun to decline, and at very low density.

In 1999 the pattern of $H$. anconai density suggests that sulfur had a negative effect on tydeids, given that the two treatments with late-season applications of sulfur (sulfur or sulfur post-bloom) had the lowest tydeid density, on average 2.5-fold lower than the treatments with early-season sulfuring (Fig. 4). English Loeb et al.(1999) also found that seven applications of wettable sulfur reduced tydeid density to near zero on the vine cultivar 'Aurora.' However, in the current study the lower density of tydeids in the sulfur or sulfur post-bloom treatments obviously had no impact on density of G. occidentalis, since these were the treatments with the highest phytoseiid densities.

Lacking an explanation due to phytoseiids or tydeids suggests that a plant-based factor is involved, which is supported by two observed patterns. First, the difference in pre-bloom versus post-bloom timing of sulfur, conducted in 1999, a variable which no study had previously analyzed. Pre-bloom sulfur produced high densities of spider mites, results similar to that of season-wide sulfur dusting, whereas reversing the timing produced low spider mite densities, results statistically equivalent to using season-wide synthetic fungicides (Table 4). This suggests that whatever effect sulfur is having, it is interacting with the phenology of the vine, and has a greater effect on spider mite density when applied earlier in the season. Whereas it is true that in the sulfur pre-bloom treatment there was an additional sulfur dust and an additional wettable sulfur application (30\% more sulfur total than postbloom), this would not seem to entirely explain the 2.5 -fold difference in spider mite density between pre- and post-bloom sulfur treatments. Second, in each year there is a long lag time between the end of sulfuring and the spider mite outbreaks. Applications of sulfur dust in April and May produced an effect (i.e., high T. pacificus density) that was seen in July, August and even September. For this reason it appears that sulfur is suppressing the ability 
of the vine to defend itself against spider mite attack. This is not unlike the phenomenon observed by Karban et al. (1997) in which a 'vaccination' of grapevines with E. willametti in the spring led to lower density of T. pacificus in mid-summer. It is well known that plants produce biochemical defenses to attack by arthropods (Karban and Baldwin 1997), and it is therefore possible that sulfur may somehow be disallowing the expression of genes needed to mount the biochemical defense to spider mite attack. This would explain the long-term effect of sulfur on spider mite density. To my knowledge, no work has been published that identifies the phytochemicals nor the genes involved in plant defense against spider mites.

Acknowledgments I thank the California Department of Pesticide Regulation, the California Agricultural Technology Institute (CATI) at California State University, Fresno, and Martin Britz of Britz Farming Inc., Fresno for providing partial funding for these studies. Thanks also to Kip Green and Gurmit Singh of Britz Farming, Inc., for their indispensable assistance in this project, including providing the field site, materials, labor and advice for the study. Thanks to Juliet Schwartz, Abebe Gebrehiewet, Jose Cantu and Kimberly Miyasaki for field and laboratory assistance. Finally, I thank Dr. Carlo Duso of the University of Padua for helpful comments on the manuscript.

\section{References}

Alston DG, Thompson SV (2004) Effects of fungicide residues on the survival, fecundity, and predation of the mites Tetranychus urticae (Acari: Tetranychidae) and Galendromus occidentalis (Acari: Phytoseiidae). J Econ Entomol 97:950-956

Auger P, Guichou S, Kreiter S (2003) Variations in acaracidal effect of wettable sulfur on Tetranychus urticae (Acari: Tetranychidae): effect of temperature, humidity and life stage. Pest Manage Sci 59:559-565

California Department of Pesticide Regulation (2006) Summary of pesticide use report data, 2005, indexed by commodity. California Environmental Protection Agency, Department of Pesticide Regulation

English-Loeb GM (1989) Non-linear responses of spider mites to drought-stressed host plants. Ecol Entomol 14:45-55

English-Loeb GM, Flaherty DL, Wilson LT, Barnett WW, Leavitt GM, Settle WH (1986). Pest management affects spider mites in vineyards. Calif Agric 40:28-30

English-Loeb GM, Norton AP, Gadoury DM, Seem RC, Wilcox WW (1999) Control of powdery mildew in wild and cultivated grapes by a tydeid mite. Biol Control 14:97-103

Flaherty DL, Wilson LT, Welter S, Lynn CD, Hanna RA (1992) Spider mites. In: Flaherty DL, Christensen LP, Lannini WT, Marois JJ, Phillips PA, Wilson LT (eds) Grape pest management. University of California, Division of Agriculture and Natural Resources, Oakland, California, pp 180-192

Hanna R, Zalom FG, Wilson LT, Leavitt GM (1997) Sulfur can suppress mite predators in vineyards. Calif Agric 51(1):19-21

Hoy MA, Standow KA (1982) Inheritance of resistance to sulfur in the spider mite predator Metaseiulus occidentalis. Entomol Exp Appl 31:316-323

James DG, Price TS, Wright LC, Perez J (2002) Abundance and phenology of mites, leafhoppers and thrips on pesticide-treated and untreated wine grapes in southcentral Washington. J Agric Urban Entomol 19:45-54

Karban R, Baldwin IT (1997) Induced responses to herbivory. The University of Chicago Press, 319 pp

Karban R, English-Loeb G, Hougen-Eitzman D (1997) Mite vaccinations for sustainable management of spider mites in vineyards. Ecol Appl 7:183-191

Prischmann DA, James DG, Wright LC, Teneyck RD, Snyder WE (2005) Effects of chlorpyrifos and sulfur on spider mites (Acari: Tetranychidae) and their natural enemies. Biol Control 33:324-334

Smith LM (1950) Mite populations on grapes. Calif Agric 4(3):13-14

SAS Institute (2001) SAS/STAT user's guide, release 8.02 ed. SAS Institute, Cary, NC

Teodoro AV, Fadini MAM, Lemos WP, Guedes RNC, Pallini A (2005) Lethal and sub-lethal selectivity of fenbutatin-oxide and sulfur to the predator Iphiseiodes zuluagai (Acari: Phytoseiidae) and its prey, Oligonychus ilicis (Acari: Tetranychidae), in Brazilian coffee plantations. Exp Appl Acarol 36:61-70

Wood BW, Reilly CC (2000) Pest damage to pecan is affected by irrigation, nitrogen application and fruit load. HortSci 35:669-672 